\title{
Conflict of Relevance and Reliability of İformation and the Global Network
}

Kazimi Parviz Firudin Oqlu (Corresponding author)

Baku State University, Azerbaijan

Email: pkazimi@mail.ru

Received: $12 / 03 / 2021$

Accepted: 20/05/2021

Published: 01/07/2021

Volume: 1 Issue: 1

How to cite this paper: Oqlu, K. P. F. (2021). Conflict of Relevance and Reliability of Information and the Global Network. Trends in Humanities and Social Sciences, 1(1), 1-2 DOI: https://doi.org/10.46809/thss.v1i1.20

Copyright (C) 2021 by author(s) and Global Talent Academy Ltd. This work is licensed under the Creative Commons Attribution International License (CC BY 4.0).

http://creativecommons.org/licenses/by/4.0/

(c) (9)

\begin{abstract}
The conflict of interests in the global information space is multifaceted conflict between manopolists and the government, sellers and consumers, information resources and consumers of information, etc. Systematic discussion and new approaches to the problem of conflict of interests can contribute to raising progressiveness. The purpose of the article is to raise the problem of conflict of interest, to model it both within the framework of an integrated system, and to find optimal solutions in the context of differentiated corporate interests. This will eliminate the manipulation of the niteres conflict in the global network.
\end{abstract}

Keywords: Information Reliability, Relevance, Global Information Space, Interests In The Information Market, Library Resources

\section{Introduction}

Since the creation of the global information space, two centers of power have emerged that can really influence information processes. The first one is corporations that both implement technological processes and manage them, actually controlling the global information space.

The second side is the state structures that own the information space, which in many cases act only as observers of the processes occurring due to their inability to influence information processes, or to confront this situation without reconciliation.

The creators of global networks and the owners of key technologies want to keep things as they are, based on freedom of speech. The "other side" argues that from a humanitarian point of view, states are trying to manage this process through the application of legislation. At the same time, they strive to maintain a monopoly on information processes, forming international information law.

The first party controls the advertising market, which is based on "free speech" and dodges taxes, and ultimately it turns out that the goal is commercial interests.

The second "country" is the various "states". Of course, states are interested in gaining a share of the advertising market, collecting taxes from the electronic market, protecting themselves from provocations, moral and ethical frameworks, and also fighting "various groups" and social "diseases" in active intervention in information processes. (Kazimi, 2018, p. 186) 
In such a conflict, interests are not "antagonistic" and can be resolved by dividing the market share, and this is exactly what happens. While the market share that is decided by the loss of small countries and the conquest of large countries is not fair, there is currently no other alternative.

This definition of a consumer circulates in the scientific community: "A consumer is a person who consumes a product or service. The customer value is based on an estimate at the time of consumption. In this review (Lai, 1995) emphasizes a dynamic view of consumption in a specific consumption context ". (Khalafov, 2013, p.36.) This "information consumer" approach does not reflect the situation at all. The assimilation of information or the purchase of goods from the information space has different mechanisms of influence.

There are also huge resources in the field of free information services in the global information space, which, due to the lack of commercial interests, attract attention by their nature, purpose and service to various interests.

It should be recognized that in many cases the "free information service" pursues either "non-open" commercial interests or political, religious, ideological, and sometimes provocative goals. Here is a Russian proverb: "Free cheese is only in a mousetrap."

What is the main feature that ensures the accuracy of information received by the consumer of information. From a very large amount of information, it is necessary to choose between sending a request and receiving information. The relevance of a keyword and response does not guarantee the accuracy of the information. The information seeker is also skeptical about the correctness of his choice against the background of serious contradictions.

\section{Conclusion}

Providing primarily library resources as a reliable source of information solves part of the problem. The fact that library resources are "in the first place" as a source of authoritative information may be a topic of its own. Library resources are one of the reliable information in the modern information flow.

In this conflict, libraries, as institutions influencing the information environment, mainly support the state and try not to lose their appeal. In this respect, libraries can act as a bridge between local, regional and global networks.

There are many opinions that library resources are authoritative information resources. (Kazimi, 2018, p.121) Analysis of library and information resources shows that the indicator of reliability is relative. However, the most important indicator is that libraries do not form a "stock of ready-made answers". The answers come from reading and knowledge. Today, the most important task of libraries is to ensure the superiority of information (knowledge) obtained as a result of reading. (Kazimi, 2017, p.97)

\section{Reference}

Khalafov A.A. (2013). Kitabxana və cəmiyyət. (Library and society) -Baku, 2013.

Kazimi P.F. (2018). İnformasiya mühəndisliyi (Information engineering).- Bak1, mutarcim

Kazimi P.F. (2021). Dynamic Development of Information Technologies, Organization of Library Services Using Digital Space and Through Social Networks. https://www.journalajess.com/index.php/AJESS/article/view/30407

Kazimi P. (2017). Sosyal kültürel ortamın oluşmasında kitap ve kütüphanelerin rolü. (The role of books and libraries in the formation of social cultural environment) http://www.tk.org.tr/index.php/TK/article/view/2794 